\title{
Voting Behaviour and Electoral Outcomes
}

Draft chapter for Developments in British Politics 10

Alan Renwick, 17 December 2015

Final manuscript, before updates and other changes at proofing stage

Current word count: $4939+104$ (further reading) +651 (references) +2475 (word equivalent of figures and tables)

Number of figures: 7

Number of tables: 2

The word equivalent of the figures ad tables of 2475 is based on estimating Tables 1 and 2 , Figures 12 and Figures 5-7 as around half a page ( 225 words) each and figures 3 and 4 as a page each (450 words)

Number of references: 36 
The general election of 7 May 2015 was seen in advance as the most unpredictable for decades. The polls put the two main parties - Conservative and Labour - almost neck-and-neck. A second consecutive hung parliament seemed very likely. It appeared that the traditional pattern of British electoral politics, where two dominant parties competed to form single-party-majority governments, might finally - having been weakened in 2010 - be consigned to history.

In fact, the election delivered no such result (see Table 1). The Conservatives increased their share of the vote compared with 2010 and secured a slim majority of seats in the House of Commons. The British electoral system appeared to have reverted to type, delivering majority power to one party on the basis of a plurality of votes. Indeed, in a sense the election was exceptional in the degree to which change did not happen. For the first time in any post-Second World War election, the vote shares of both main parties moved by less than 2 percentage points. Those parties' seat totals change by fewer than thirty seats each. The prime minister remained in office. The composition of government changed only because the Conservatives moved from just under to just over the majority threshold.

[Table 1 about here]

Beneath this surface calm, however, the 2015 election saw two dramatic shifts. First, the combined vote share of the three traditional parties - Conservatives, Labour, and Liberal Democrats - dropped precipitously. Their vote share in Great Britain (that is, excluding Northern Ireland, which has its own party system), having never before dropped below 90 per cent, fell to just 76.9 per cent. This reflected a collapse in support for the Liberal Democrats, while the United Kingdom Independence Party (UKIP) was the largest beneficiary. Second, the election in Scotland delivered a political earthquake. The Scottish National Party (SNP) rose from six of Scotland's fifty-nine seats to fifty-six, reducing the three traditional UK parties to just one apiece. For the first time, four different parties won the election in the UK's four constituent nations.

In important ways, these patterns were products of short-term political events and realities: Ed Miliband's failure to connect with voters; the hit on the Liberal Democrats from entering government and compromising on many policies; the charisma of Nigel Farage in appealing to voters who felt disconnected from the political elite; the rise of Scottish nationalism around the 2014 referendum on independence; the corresponding fear among many voters in England and Wales of government in Westminster wagged by an independence-focused Scottish tail.

But we can understand the roles of such factors best by seeing how they fitted into deeper shifts in the nature of elections in the UK. The 2015 election did not spring from nowhere: it reflected trends that have been apparent for forty years.

Two broad shifts deserve attention: change in the voting behaviour of citizens; and change in the institutions of elections themselves. Voters have become much more detached than they were in the early post-war decades from the traditional political parties and much more inclined either to turn to a different party or not to vote at all. And though the electoral rules for Westminster elections have remained largely unaltered - a bid to replace the traditional single-member plurality (SMP - or "firstpast-the-post") voting system with the alternative vote (AV) system in a referendum in May 2011 was defeated by a large margin - a range of electoral systems have proliferated at other elections. Indeed, Westminster elections and local elections in England and Wales are now the only public elections in the UK where plurality rule survives. 
This chapter begins by outlining changes in citizens' approach to voting, the deeper societal trends that underlie this shift, and the manifestations of these patterns in 2015. It then examines how these changes have been reflected in electoral trends over recent years. Finally, it considers the impact of electoral systems, looking at patterns across a range of elections across the UK.

\section{Citizens' Changing Approaches to Voting and Politics}

It is often said that democracy in the UK - as in much of the industrialized world - is in crisis: that voters are disengaged and dissatisfied as never before and that the traditional institutions of democratic politics are failing to respond (e.g., Lent 2014). Whether this is accurate or not is debated: Norris (2011: 102-15), for example, points out that there is no clear long-term decline in satisfaction with democracy or trust in politicians as revealed by surveys. What does appear clear, however, is that, while, in the past, voters, however sceptical they were about politicians, were bound into politics and electoral democracy by their ties to political parties, that is no longer the case. In the early 1950s, the three main UK parties - Conservative, Labour, and the Liberals - claimed around 4 million members; by 2013, their combined membership was less than a tenth of that (Keen 2014). Though the final months of 2014 saw surging membership for the SNP and Greens, and the months after the 2015 election saw membership growth for Labour and the Liberal Democrats too, there is little reason to think these changes are more than the latest blip in a general downward trend. Opinion surveys show steady decline since around 1970 in willingness to identify with a political party among the electorate as a whole (Denver, Carman, and Johns 2012: 71).

This reflects a profound shift in how voters relate to politics. Whereas in the early post-war decades, voters were typically content to throw in their lot with one party and stick with it through successive elections, today more voters are willing to "float" from one party to another. Whereas once voting behaviour was strongly shaped by stable class identities (Butler and Stokes 1974: 77; Pulzer 1967: 89), today, those identities have weakened and fragmented (Denver, Carman, and Johns 2012: 66-70). Instead, the dominant interpretation of how voters decide whom to vote for today is the so-called "valence model". According to this, parties and voters agree on most things: the economy should grow; unemployment should be low; healthcare and education should be good. Elections are fought as contests not among alternative conceptions of the future, but among alternative teams of leaders seeking to show themselves competent to deliver what people want. The key to electoral success is thus a reputation for competence, not a set of novel ideas (Clarke et al. 2004; Denver Carman, and Johns 2012: 90-122).

Equally, we should not simplify such trends too far. Class was never the only determinant of voting (Clarke, Sanders, Stewart, and Whiteley 2004: 73), and it still matters today: as Denver (2015: 17-19) points out, the Conservatives do best where large numbers of managers and professional live, while Labour do so in constituencies with most manual workers. Ethnicity has an effect too (Heath, Fisher, Sanders, and Sobolewska 2011). Furthermore, those who vote for smaller parties often do so precisely because they dislike valence-style politics, in which politicians, seeking the broadest possible support, say little of substance to avoid putting anyone off.

These patterns were visible in the 2015 general election. The most reliable evidence will come in the reports of the British Election Study, which are unavailable at the time of writing. It appears clear, however, that valence politics dominated the battle between the Conservatives and Labour: David Cameron consistently outpolled Ed Miliband by a wide margin when voters were asked who would 
make the best prime minister, and the Conservatives scored better in terms of perceived economic competence (Denver 2015: 23). At the same time, those who turned to UKIP or the Greens clearly wanted very different kinds of politics.

The result in Scotland, challenges the valence model, but starkly illustrates the degree to which voters have freed themselves of traditional party ties. Scottish electoral politics had, until 2014, elegantly illustrated the rise of valence politics. Voters had increasingly differentiated their votes in Holyrood elections from those in Westminster in pursuit of the team who looked most likely to deliver competent governance at each level. Thus, though the SNP won the Scottish Parliament election in 2007, Labour returned to an easy victory in Scotland in the UK general election of 2010 (Mitchell and van der Zwet 2010). But the nationalist wave that grew through the 2014 independence referendum swept that pattern away. It unleashed polarization around a policy question that appears destined to dominate Scotland's electoral politics for some time.

\section{Symptoms of Electoral Change at Westminster}

If voters are no longer as attached as they were to specific political parties, we can expect three principal changes in their voting habits over time. First, if one of the reasons citizens voted in past elections was a desire to express their partisan identities, a weakening of those identities should reduce electoral turnout. Second, voting should be more volatile: we should expect voters to change whom they vote for more readily from election to election. Third, given the breakdown of class-based politics, we should expect a rise in the number of parties that voters are willing to support. This section investigates each of these possible patterns in turn in relation to UK general elections.

Figure 1 confirms that turnout has indeed fallen, the great bulk of the change having occurred with remarkable speed between 1992 (when turnout was probably pushed above trend by a close race) and 2001 (when it was below trend, at least in part because the outcome was a foregone conclusion).

[Figure 1 about here]

The 2015 election - in which 66.2 per cent of those registered to vote turned out - continued a slow turnout recovery that began in 2005. But participation in 2015 was probably boosted by the exceptionally tight pre-election polls. And it remained lower than at any other modern general election before 2001.

Electoral volatility refers to the degree of change in whom voters support from one election to the next. Figure 1 charts it since 1950 (1945 is not included because of the long gap since the preceding election, in 1935). Specifically, it shows net volatility, which is based on changes in the total vote shares for each party. In reality, even where all the parties' vote shares are unchanged, there is some movement among voters: in 2015, for example, though Labour's vote share changed only slightly, it gained many votes from former Liberal Democrats while losing others to UKIP. We normally focus on net volatility because it is impossible to see such inter-party "churn" from the official election results.

As Figure 1 shows, volatility in 2015 was the highest since 1950. The change in the Liberal Democrats' vote share (15 percentage points) was the largest experienced by any party (up or down) during this 
period. The rise in UKIP's share (10 percentage points) exceeded all other post-war changes but one (the fall in Conservative support in 1997). This extended a pattern that has been apparent since 1974 . Before that year, volatility was always limited: in no election did it reach the average for the period as a whole. Since 1974 , however, volatility has been much higher at many - though not all - elections.

Figure 2 presents information on the number of parties that matter and confirms the intuition that British elections are no longer simple two-party affairs. The black top line (which plots to the righthand axis) shows the combined vote share of the Conservative and Labour parties at each election since 1945. Since peaking in 1951 at 96.7 per cent, this has fallen steadily, and in 2010 hit a low of 65.0 per cent. It recovered slightly (to 67.3 per cent) in 2015.

The two grey lower lines in Figure 2 offer a more sophisticated indicator of the number of parties, taking into account the strength of all the parties, not just the big two. The effective number of parties in terms of the votes cast at each election (ENPV) has been rising steadily since the 1950s and reached a new high in 2015 of 3.93. The effective number of parties calculated by the parties' shares of the seats in Parliament (ENPS) has taken longer to respond - we discuss this difference shortly, when we turn to electoral systems. But it too has been higher in the last three elections than at any other time since the Second World War.

[Figure 2 about here]

The analysis in this section shows that 2015 was indeed an exceptional election: both the dispersion of votes across multiple parties and the change in voting patterns since the previous election where higher than at any other time in the post-war era. But this result did not come out of the blue: rather, it reflected an intensification of trends that have been ongoing since at least the 1970s. Voters' disengagement from the traditional parties has created an environment in which - given such shortterm circumstantial factors is were mentioned in the chapter introduction - an election quite unlike any other in the UK could occur.

Before we consider the impact of electoral systems, it is worth while to consider how these patterns in the UK relate to those experienced in other democracies. Figure 3 compares the UK trends with those across the sixteen European countries that have been continuously democratic since at least 1950 (the "E16"). The upper panel shows average turnout decade-by-decade; the lower panel does the same for electoral volatility and the effective number of parties (in terms of votes cast). The trend towards rising volatility is even more consistent across democratic Europe than it is in the UK: volatility across the E16 has risen in every decade since the 1950s, most rapidly in the first half of the 2010s. The rise in the number of parties has been broadly parallel to that found in the UK. The general fall in turnout has been somewhat smaller than that in the UK, but this masks considerable variation between countries.

[Figure 3 about here]

These patterns again point to the importance of looking at deep underlying factors to understand electoral outcomes in the UK. If the particular personalities or tactics at play in any single election were all that mattered, we would not find such consistent trends across such long periods and so many 
countries. This suggests that we cannot expect a "return to normal" - to traditional two-party politics - any time soon.

\section{The Impact of Electoral Systems}

So far this chapter has examined voting behaviour and its social underpinnings. But electoral outcomes are also shaped by the rules governing the sorts of vote that voters can cast and how those votes are translated into seats - that is, by electoral systems. The previous section held the electoral system constant by focusing solely on Westminster elections. Since 1950, all Commons seats have been filled through SMP: the country is divided into constituencies that each elect one MP; whichever candidate secures most votes wins the seat. Beyond Westminster, however, the rules vary widely. In fact, voters in parts of the UK face a greater diversity of electoral systems than anywhere else on Earth.

This section starts by surveying the electoral systems now used around the UK. It then analyses the impact of those systems upon election results. Finally, it considers how different systems might have affected the 2015 outcome.

\section{Electoral Systems in the UK Today}

Figure 4 sets out the electoral systems in use in public elections around the UK today. These systems belong to two broad families: majoritarian and proportional. Majoritarian systems generally involve competition for one position: either a single executive post such as a mayor or a seat in a singlemember constituency. The candidate with most support wins that position. In proportional systems, by contrast, multiple positions are available in each competition and are allocated to contestants in proportion to the votes they win.

[Figure 4 about here]

Each of these families contains multiple siblings. While all majoritarian systems give the position to the candidate with most votes, they differ in how they work out which that candidate is. Under SMP, voters vote for one candidate, and whoever wins most votes is elected. Under supplementary vote (SV), by contrast, voters express their first and second preferences, while under AV they can rank as many candidates as they wish. Lower preferences come into play if no candidate gets an absolute majority of first preferences. SV is currently used to choose local mayors wherever they are directly elected (most notably, in London) and for police and crime commissioners throughout England and Wales outside London. AV was proposed for Westminster elections in the referendum of May 2011 (see below), but its defeat there means it has only very limited usage in the UK: for local council byelections in Scotland.

Until the late 1990s, proportional representation (PR) electoral systems were confined in the UK to Northern Ireland: the single transferable vote (STV) form of PR has been used for Northern Ireland's local elections since 1973 and its European Parliament elections since 1979. Proportional systems became much more widespread, however, through the Blair government reforms between 1997 and 2001: closed-list PR was adopted for European Parliament elections in Great Britain; mixed-member 
proportional (MMP) systems are used for the devolved assemblies in Scotland, Wales, and London; and STV is employed for elections to the Northern Ireland Assembly and for Scottish local elections. (For details of these systems, see Farrell 2011; Renwick 2011.)

\section{Electoral Systems and the Party System}

Electoral systems can be expected to have two main effects upon the distribution of power across parties. First, the degree of proportionality in the electoral rules should influence the proportionality also of outcomes: the more electoral systems are designed to distribute power proportionally across parties, the more likely they are in fact to do so. Second, electoral systems affect the number of parties: majoritarian systems tend to concentrate power in the hands of a few parties, while proportional systems often spread it out across many.

These effects are illustrated for the 2015 election in the left-hand panel of Figure 5. As almost always occurs under SMP, the large parties won greater shares of the seats than of the votes, while the reverse was true for the smaller parties. Indeed, this was dramatically so. The Conservatives won a 14-percentage-point bonus in their seat share ( 51 per cent) over their vote share ( 37 per cent). Even Labour, though it lost the election badly, did better on seats ( 36 per cent) than votes ( 30 per cent). By contrast, UKIP, with 12 per cent of the votes, secured just one seat ( 0.15 per cent), while the Liberal Democrats won 1.2 per cent of the seats from 7.9 per cent of the votes. The performance of the SNP and, on a smaller scale, Northern Ireland's Democratic Unionist Party (DUP) might appear anomalous: they are small parties that scored better on seats than on votes. The reason is that, within their particular areas, they are large parties, able to reap the benefits of SMP. (For further analysis of the electoral system in 2015, see Curtice 2015.)

[Figure 5 about here]

The right-hand panel of Figure 5 compares this with the result of the most recent European Parliament elections (in Great Britain only, because Northern Ireland uses a different system). Here too, the larger parties tended to do better in terms of seats than votes, at the expense of smaller parties - the electoral system used does not achieve perfect proportionality. But the differences were generally smaller than in the general election.

Gallagher has developed an index for comparing overall levels of proportionality in different elections (see Gallagher and Mitchell 2005: 602-5). Figure 6 shows the values of this index for the last four elections to various bodies. Higher numbers indicate higher levels of disproportionality. Thus, as expected, disproportionality is higher in general elections - using SMP - than in any of the elections under PR. Still, there is significant disproportionality even in the supposedly proportional systems. It is highest in Wales, where there are just four PR seats per region - too few to compensate for all the disproportionalities in the constituency results.

[Figure 6 about here] 
We can repeat this analysis for the number of parties. Figure 7 charts the effective number of parties - calculated in terms of the votes cast - for recent elections to a range of bodies. It shows that the number of parties has generally been lower in Westminster elections than under the various proportional systems. But the differences are not large. Indeed, going beyond the data shown, the effective number of parties in both Scotland and Northern Ireland in the general election in 2010 was higher than in the corresponding devolved assembly elections a year later.

[Figure 7 about here]

To understand what is going on here, it is useful to consider why majoritarian systems might lead to fewer parties. The French political scientist Maurice Duverger (1954) famously argued that electoral systems have two effects - mechanical and psychological - upon the number of parties. The mechanical effect comes from how the system translates votes into seats. In majoritarian systems, small parties can win seats only if they have local pockets of strong support; otherwise, the large parties win everywhere. In more proportional systems, however, the same votes give smaller parties more seats. The psychological effect, meanwhile, comes from the fact that voters and politicians know about the mechanical effect and adjust their behaviour accordingly: voters might avoid casting a "wasted vote" for a candidate with little prospect of victory; politicians might avoid creating a new party that faces a high barrier to success.

Because Figure 7 shows the effective number of parties in terms of votes (ENPV), it takes account only of the psychological effect. To capture the mechanical effect as well, we need to look at the effective number of parties in terms of seats (ENPS). Indeed, when we looked at both measures in Figure 2, we saw that, while ENPS has increased somewhat in recent elections, it has risen much less than ENPV. And if we repeated the analysis of Figure 7 for ENPS, we would find a larger gap between the plurality elections for Westminster and the proportional elections elsewhere. The mechanical effect, therefore, continues to function.

But the trend shown in Figure 2 suggests that the psychological effect has weakened: voters seem readier to vote for smaller parties today than in the past. Part of the explanation for this is that Duverger's argument really applies to individual constituencies, not the nationwide result: voters, he predicts, will choose between the serious contenders; but the contest in each constituency is separate; so what matters is who has a chance of winning locally. If different parties are strong in different parts of the country, that could lead to high ENPV even when Duverger's mechanisms are working fully. Indeed, the rise of nationalist parties in Scotland and Wales and the tendency of Conservative and Labour votes to concentrate in the south and north respectively do indicate a regional differentiation of voting patterns.

Even if this is the case, however, the dispersion of votes within constituencies has increased too. The combined vote share of the top two candidates in each constituency peaked in 1951 at an average of 97.8 per cent (author's calculations from data kindly supplied by Jennifer Hudson). By 1997, however, it had fallen to 80.7 per cent, and by 2015 to 75.5 per cent. So voters today are apparently more willing to vote for candidates with little chance of winning than in the past. The power of the electoral system to shape the election result has weakened.

There are several possible explanations for this pattern. One could be that, now that many voters are less engaged with politics, they have less understanding of who the main contenders in their area are. 
But many voters clearly do understand what they are doing. As voters see less difference between the main parties, they may think there is more value in sending the political establishment a message by supporting an outsider than in influencing which of the mainstream parties wins. They might also hope that a gradual build-up of support for a small party could foster long-term change in electoral dynamics. Thus, for many voters, the characterization of a vote for a hopeless candidate as a "wasted vote" is no longer valid.

A further explanation is that the proliferation of proportional electoral systems away from Westminster may influence how people vote in general elections too. It is difficult for new parties to break into Westminster politics in part because, under SMP, such parties struggle to overcome the initial hurdle of looking like credible contenders: so long as they are viewed as also-rans, they attract little attention or support. If they overcome the credibility gap in proportional elections, however, that can seep into their subsequent performance under SMP. UKIP's success in winning the 2014 European Parliament elections, for example, raised its profile and credibility and fuelled its entry to Westminster politics. Similarly, the SNP initially developed its support base and network of activists through Holyrood elections before breaking through at Westminster.

Thus, even if SMP constrains the party system less today than in the past, electoral systems still matter. That fact was cruelly apparent to UKIP and Liberal Democrat supporters in the wake of the 2015 election, while Conservative and SNP supporters were its beneficiaries.

\section{Would AV Have Made a Difference?}

Under the Conservative-Liberal Democrats coalition deal, a referendum was held in May 2011 on whether to change the system for electing the House of Commons from SMP to AV. The Conservatives are long-standing supporters of SMP, the Liberal Democrats of PR. The AV referendum was a compromise between them. As noted above, AV is not a proportional, but a majoritarian, system. The Liberal Democrats hoped it would provide a stepping stone to more fundamental reform. They expected - and previous projections predicted (e.g., Sanders, Clarke, Stewart, and Whiteley 2011) that they would gather many second preferences from other parties' supporters, thereby gaining extra seats. The Conservatives, meanwhile, hoped to defeat the measure, and could reassure themselves that, even if adopted, AV would likely change the distribution of seats only marginally.

In the end, the Conservatives' calculations proved correct: AV was heavily defeated, by 68 per cent to 32 per cent. The idea of electoral reform did not capture the public imagination, and many voters opted for the familiarity of the status quo (Laycock, Renwick, Stevens, and Vowles 2013).

Nevertheless, we can ask how AV - or, indeed, more fundamental electoral reform - would have affected the election outcome in 2015. There was some pre-election speculation that the Conservatives might come to rue their decision to oppose AV: the rise of UKIP might split the right-ofcentre vote under SMP, allowing Labour or the Liberal Democrats to secure extra seats (Eaton 2013; Hanretty 2015). Following the Conservatives' unexpected victory, such possibilities were forgotten. But it is useful to examine the evidence.

Table 2 compares the actual election result with projected seat distributions under four alternative systems: a very pure version of PR where all seats (in Great Britain) are distributed in a single district with no electoral threshold; a more realistic form of PR, where seats are distributed in the regions used for European Parliament elections with a 5 per cent threshold; STV applied in small multimember constituencies; and AV itself. 
[Table 2 about here]

Such projections should be treated with caution. Those for pure and regional PR are calculated simply by applying the specified electoral system to the votes that were actually cast. They therefore shows mechanical effects, but take no account of any psychological effect. The STV and AV estimates draw on information from a large-scale survey for the Electoral Reform Society in which respondents were asked to rank parties in order of preference (Garland and Terry 2015: 33-5). This allows psychological as well as mechanical effects to be explored. But it still asks voters who experienced the election under SMP to imagine their hypothetical preferences under a different system. Had STV or AV actually been used, the campaign might have unfolded differently, leading to different final preferences.

Still, accepting the projections for what they are, we can first see the degree to which the actual result deviated from a purely proportional result, reflecting the considerable disproportionalities already discussed. Regional PR with a 5 per cent threshold would have secured high proportionality in most respects, but would still have underrepresented the Green Party, who passed 5 per cent in only two regions. The small constituencies used for the STV projection lead to greater deviation from pure proportionality, but still no party would have approached an overall majority. Finally, two features of the AV projection are notable. First, it is very similar to the actual result, confirming AV's limited differences from SMP. Second, the Conservatives would, as predicted, have done better under AV but only marginally.

\section{Conclusions}

The 2015 general election restored single-party majority government to the UK. Beyond that apparent return to "normal" politics, however, the result was exceptional in many ways. Electoral volatility and support for non-traditional parties both hit record highs. The Liberal Democrats suffered losses unseen by any party in the post-war period. UKIP and the SNP (in very different ways) experienced record gains. These changes did not spring from nowhere. Rather, they were the latest manifestations of long-term trends that have been building since the 1970s. Voters have become increasingly disengaged from their traditional parties and increasingly willing to experiment with new alternatives. In recent years, these trends have been strengthened by the introduction of a range of innovative electoral systems, whose effects have seeped back to Westminster. Despite the surface calm, the 2015 election confirmed that UK electoral politics has changed profoundly.

\section{Further Reading}

Denver, Carman, and Johns (2012) gives an excellent introduction to elections and voting in the UK. For short, pithy introductions to a wide range of voting-related issues, see Cowley and Ford (2014) the chapters are aimed at the general reader, but they contain suggests for further reading that allow 
deeper digging. The largest study of electoral behaviour in the UK is the British Election Study; the latest analysis from the BES team is Whiteley et al. (2013). Studies of the 2015 election include Cowley and Kavanagh (2015) and Geddes and Tonge (2015). For s introductions to electoral systems, see Farrell (2011) and Renwick (2011). 
Figures and Tables

Table 1. General Election Results: 2010 and 2015 Compared

\begin{tabular}{|c|c|c|c|c|c|c|}
\hline & \multicolumn{3}{|c|}{ Votes } & \multicolumn{3}{|c|}{ Seats (out of 650 ) } \\
\hline & $\begin{array}{c}2010 \\
(\%)\end{array}$ & $\begin{array}{c}2015 \\
(\%)\end{array}$ & $\begin{array}{l}\text { Change (\%- } \\
\text { age points) }\end{array}$ & 2010 & 2015 & Change \\
\hline Conservative & 36.0 & 36.8 & +0.8 & 306 & 330 & +24 \\
\hline Labour & 29.0 & 30.4 & +1.5 & 258 & 232 & -26 \\
\hline Lib Dem & 23.0 & 7.9 & -15.1 & 57 & 8 & -49 \\
\hline UKIP & 3.1 & 12.6 & +9.5 & 0 & 1 & +1 \\
\hline Green & 1.0 & 3.8 & +2.8 & 1 & 1 & - \\
\hline SNP & 1.7 & 4.7 & +3.1 & 6 & 56 & +50 \\
\hline Plaid Cymru & 0.6 & 0.6 & +0.0 & 3 & 3 & - \\
\hline DUP & 0.6 & 0.6 & +0.0 & 8 & 8 & - \\
\hline Sinn Féin & 0.6 & 0.6 & -0.0 & 5 & 4 & -1 \\
\hline SDLP & 0.4 & 0.3 & -0.0 & 3 & 3 & - \\
\hline UUP & 0.3 & 0.4 & +0.0 & 0 & 2 & +2 \\
\hline Alliance & 0.1 & 0.2 & +0.1 & 1 & 0 & -1 \\
\hline Others & 4.2 & 1.7 & -2.5 & 2 & 2 & - \\
\hline
\end{tabular}

Source: Author's calculations based on results at BBC (2015). 
Figure 1. Turnout and Net Volatility at UK General Elections since 1945

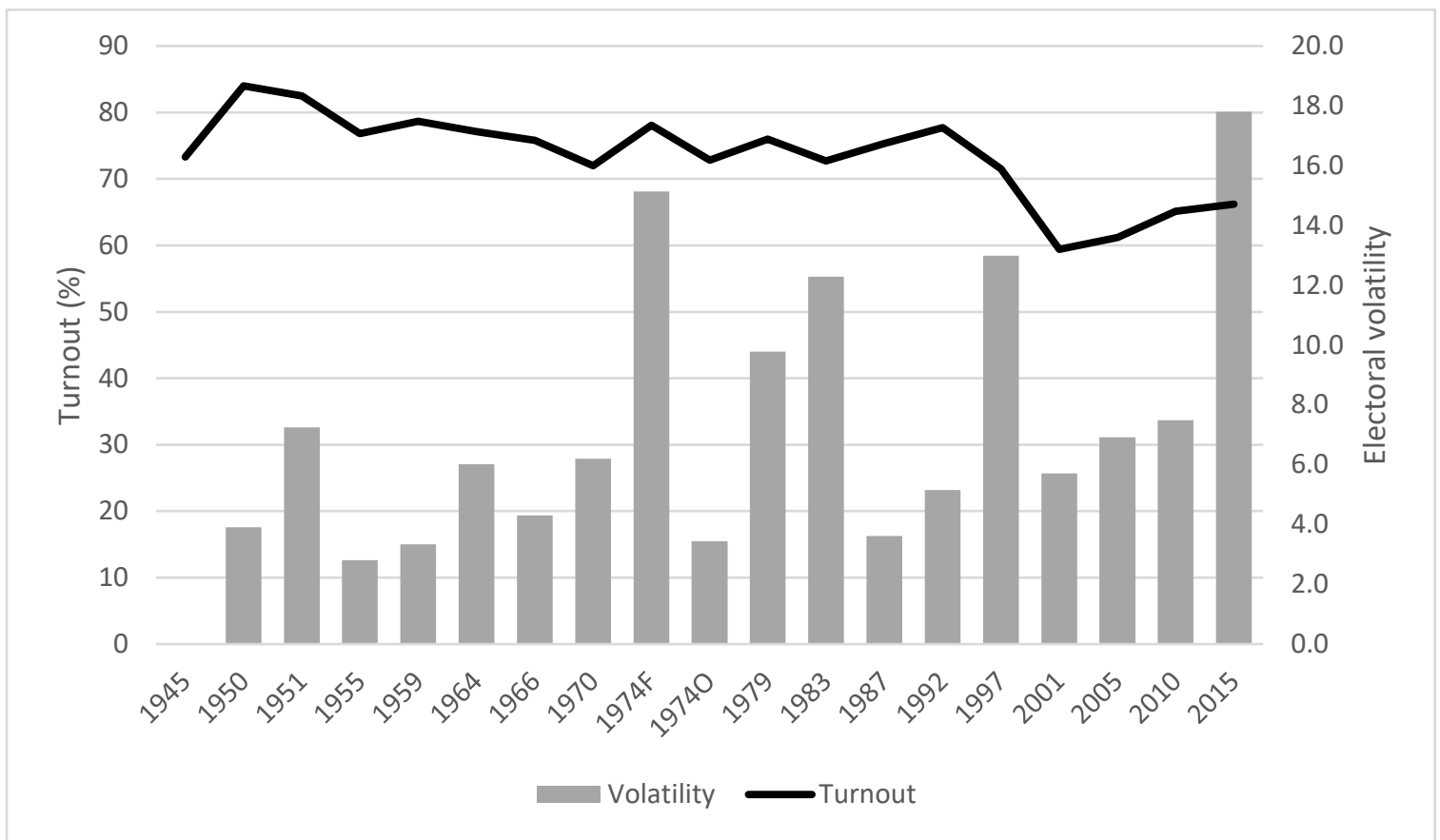

Note: Net volatility is measured by Pedersen's index, which takes the value of 0 if all parties win vote shares identical to those in the previous election and 100 if all votes are cast for parties that received no votes in the preceding election. It is calculated by adding up the changes in the vote percentages of all parties (ignoring whether they are increases or decreases) and then dividing by 2 .

Sources: Turnout: Kavanagh and Cowley (2010: 350-1); Hawkins, Keen, and Nakatudde (2015: 7). Volatility: Calculated by the author from data in Mackie and Rose (1991), Nohlen and Stöver (2010), and BBC News $(2010,2015)$. 
Figure 2. Effective Number of Parties and Two-Party Vote Share at UK General Elections since 1945

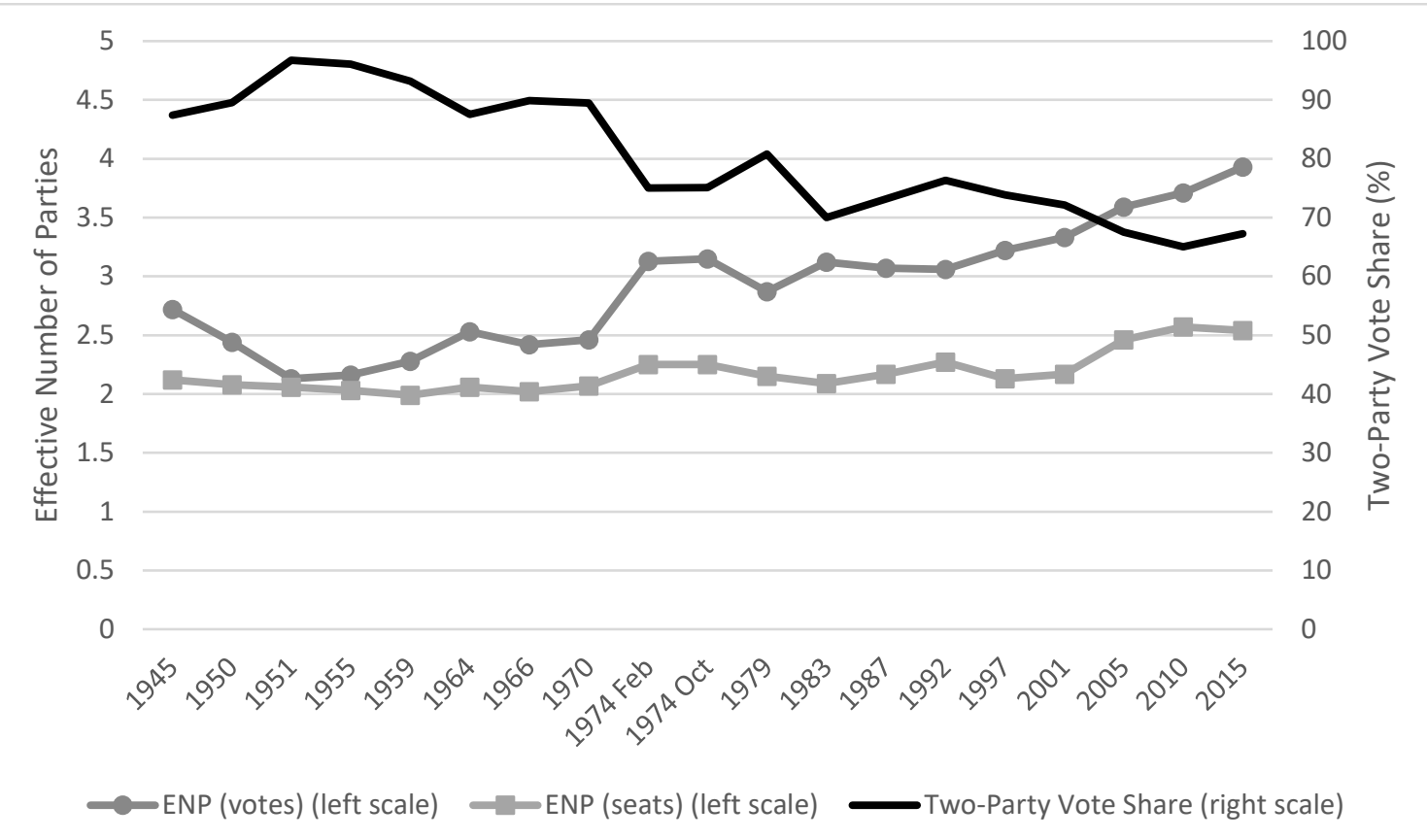

Notes: ENP is the Effective Number of Parties, calculated in terms of the parties' shares of the votes cast in the election and of the seats won in Parliament. Two-Party Vote Share is the combined vote share of the Conservative and Labour parties.

Sources: Gallagher (2015) and author's calculations. 
Figure 3. Electoral Trends in the UK and Europe Compared

(a) Electoral Turnout

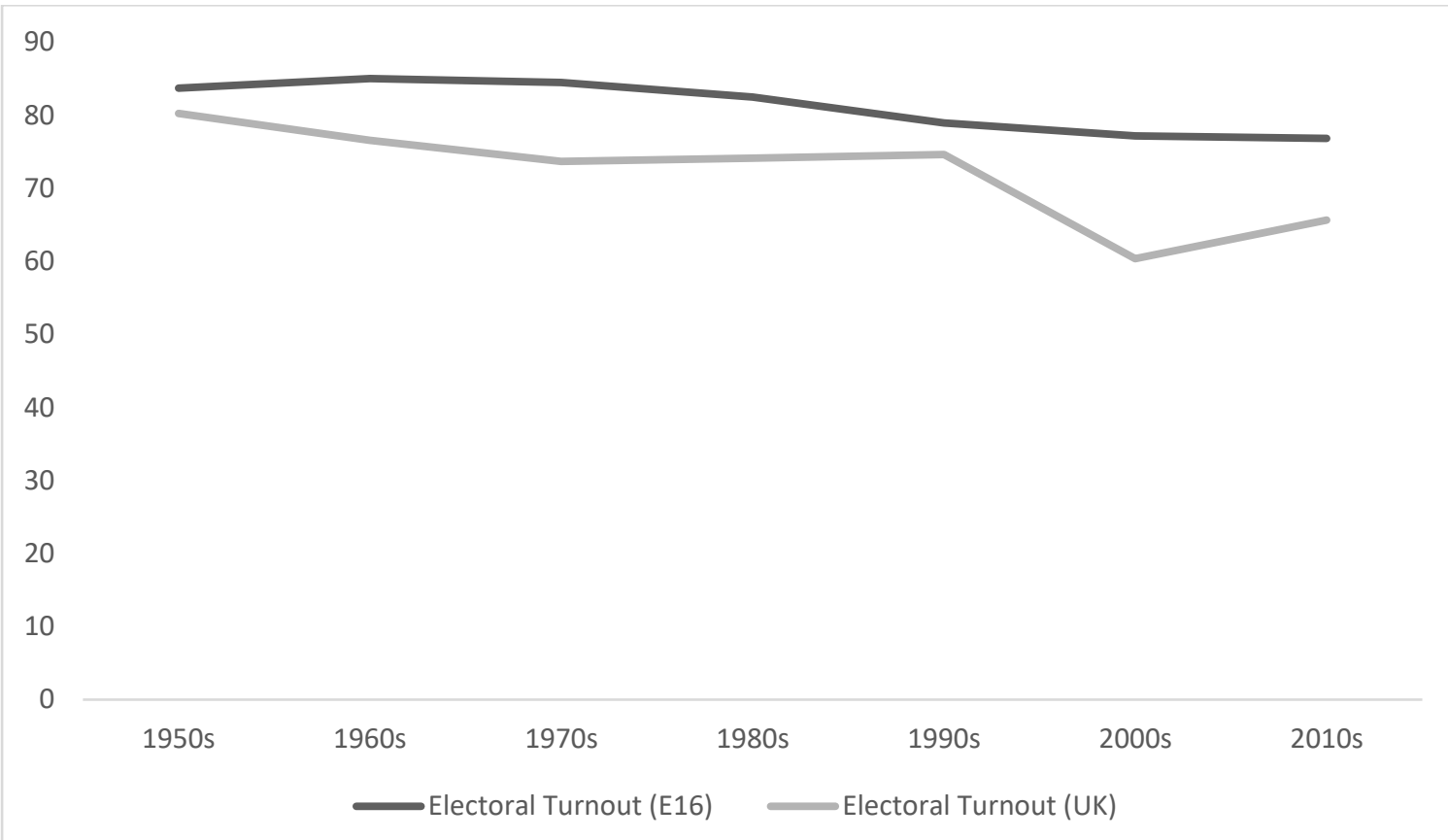

(b) Electoral Volatility and Effective Number of Parties

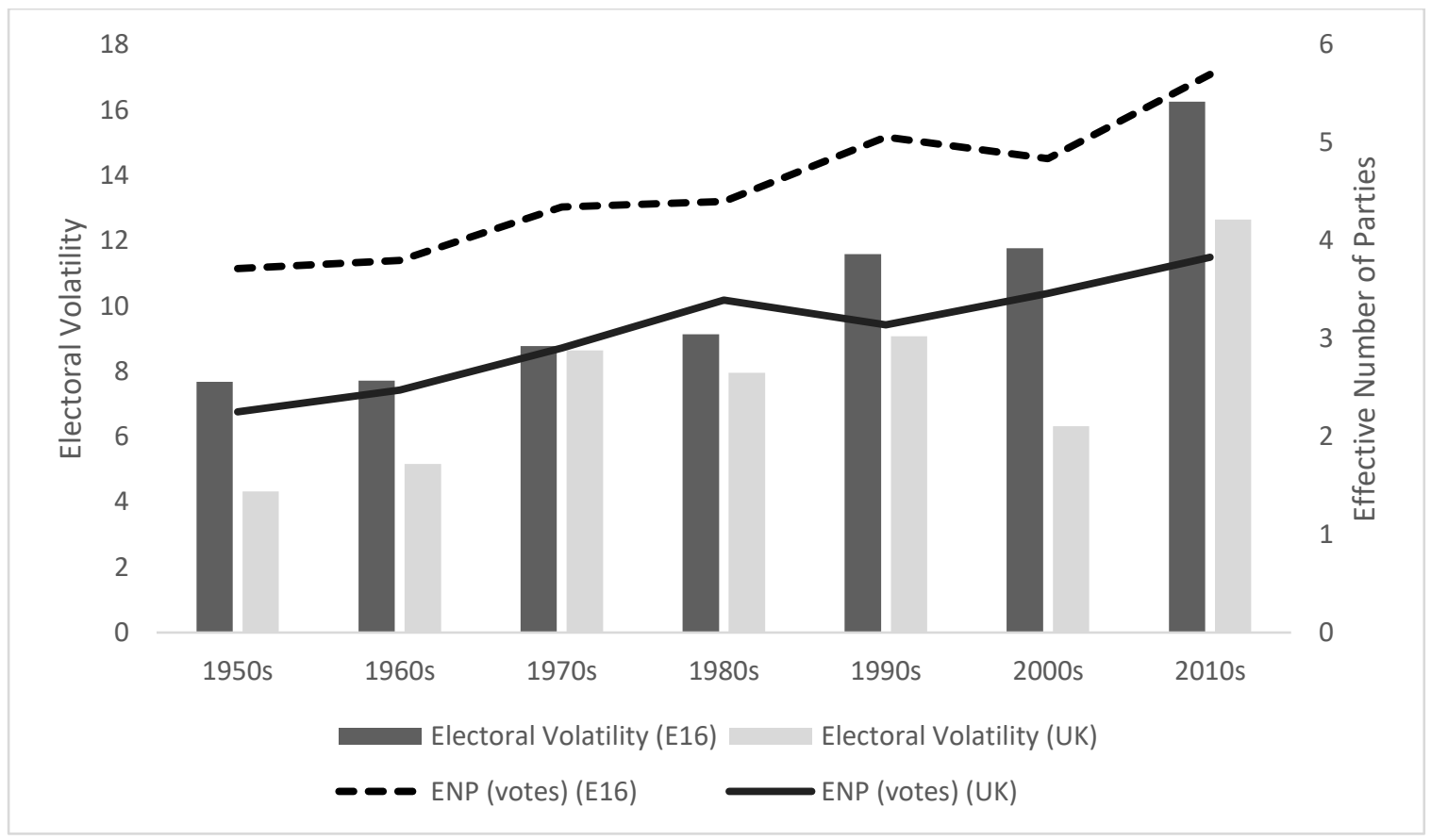

Sources: Author's calculations from data in Dassonneville (2015), Gallagher (2015), and IDEA (2015). 
Figure 4. Electoral Systems in the UK Today

\begin{tabular}{|c|c|c|c|c|c|c|}
\hline System family & \multicolumn{3}{|c|}{ Majoritarian } & \multicolumn{3}{|c|}{ Proportional } \\
\hline Specific system & $\begin{array}{l}\text { Single-Member } \\
\text { Plurality (SMP) }\end{array}$ & $\begin{array}{l}\text { Supplementary } \\
\text { Vote (SV) }\end{array}$ & $\begin{array}{l}\text { Alternative Vote } \\
\text { (AV) }\end{array}$ & Closed-List PR & $\begin{array}{l}\text { Mixed-Member } \\
\text { PR (MMP) }\end{array}$ & $\begin{array}{l}\text { Single Transfer- } \\
\text { able Vote (STV) }\end{array}$ \\
\hline $\begin{array}{l}\text { Units of } \\
\text { competition }\end{array}$ & $\begin{array}{l}\text { single-member } \\
\text { constituencies or } \\
\text { single offices }\end{array}$ & $\begin{array}{l}\text { single-member } \\
\text { constituencies or } \\
\text { single offices }\end{array}$ & $\begin{array}{l}\text { single-member } \\
\text { constituencies or } \\
\text { single offices }\end{array}$ & $\begin{array}{l}\text { multi-member } \\
\text { constituencies }\end{array}$ & $\begin{array}{l}\text { mix of single and } \\
\text { multi-member } \\
\text { constituencies }\end{array}$ & $\begin{array}{l}\text { multi-member } \\
\text { constituencies }\end{array}$ \\
\hline $\begin{array}{l}\text { Votes that } \\
\text { voters can cast }\end{array}$ & $\begin{array}{l}\text { single vote for } \\
\text { one candidate }\end{array}$ & $\begin{array}{l}\text { first and second } \\
\text { preferences } \\
\text { among candidates }\end{array}$ & $\begin{array}{l}\text { ranking of all } \\
\text { candidates }\end{array}$ & $\begin{array}{l}\text { single vote for } \\
\text { one party list }\end{array}$ & $\begin{array}{c}\text { one vote for a } \\
\text { candidate and one } \\
\text { for a party list }\end{array}$ & $\begin{array}{l}\text { ranking of all } \\
\text { candidates }\end{array}$ \\
\hline $\begin{array}{l}\text { How votes } \\
\text { translate into } \\
\text { outcomes }\end{array}$ & $\begin{array}{l}\text { the candidate with } \\
\text { most votes wins }\end{array}$ & $\begin{array}{l}\text { preferences are } \\
\text { counted in } \\
\text { sequence until a } \\
\text { candidate has an } \\
\text { absolute majority }\end{array}$ & $\begin{array}{l}\text { preferences are } \\
\text { counted in } \\
\text { sequence until a } \\
\text { candidate has an } \\
\text { absolute majority }\end{array}$ & $\begin{array}{c}\text { seats are distribut- } \\
\text { ed among parties } \\
\text { in proportion to } \\
\text { votes }\end{array}$ & $\begin{array}{l}\text { constituency seats } \\
\text { go to candidates } \\
\text { with most votes; } \\
\text { other seats are } \\
\text { distributed to give } \\
\text { proportionality } \\
\text { across parties }\end{array}$ & $\begin{array}{c}\text { preferences are } \\
\text { counted until } \\
\text { sufficient } \\
\text { candidates meet a } \\
\text { quota }\end{array}$ \\
\hline $\begin{array}{l}\text { Bodies and } \\
\text { offices elected } \\
\text { by this system in } \\
\text { the UK }\end{array}$ & $\begin{array}{c}\text { House of } \\
\text { Commons; local } \\
\text { councils in England } \\
\text { and Wales }\end{array}$ & $\begin{array}{l}\text { elected mayors; } \\
\text { police and crime } \\
\text { commissioners }\end{array}$ & $\begin{array}{l}\text { local councils in } \\
\text { Scotland (by- } \\
\text { elections only) }\end{array}$ & $\begin{array}{l}\text { European } \\
\text { Parliament seats in } \\
\text { Great Britain }\end{array}$ & $\begin{array}{c}\text { Scottish } \\
\text { Parliament; Welsh } \\
\text { Assembly; London } \\
\text { Assembly }\end{array}$ & $\begin{array}{l}\text { local councils in } \\
\text { Scotland and NI; NI } \\
\text { Assembly; Euro- } \\
\text { pean Parliament } \\
\text { seats in NI }\end{array}$ \\
\hline
\end{tabular}


Figure 5. Proportionality in the 2015 General Election and the 2014 European Elections

(a) 2015 General Election (UK)

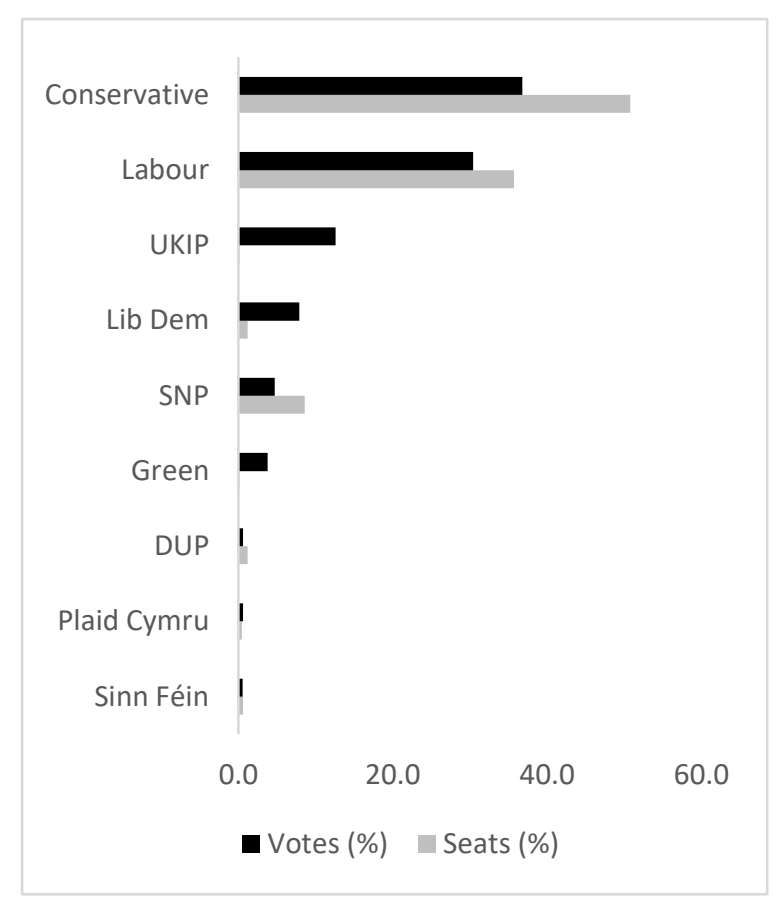

(b) 2014 European Parliament Elections (GB)

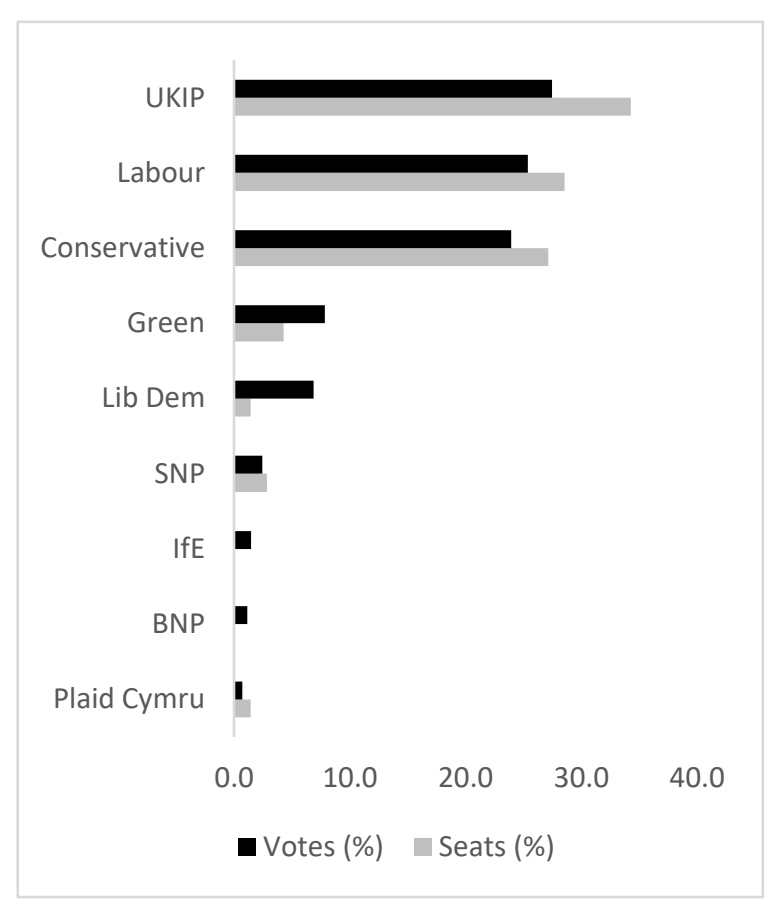

Sources: BBC News $(2014,2015)$. 
Figure 6. Gallagher's Index of Disproportionality in Recent UK Elections

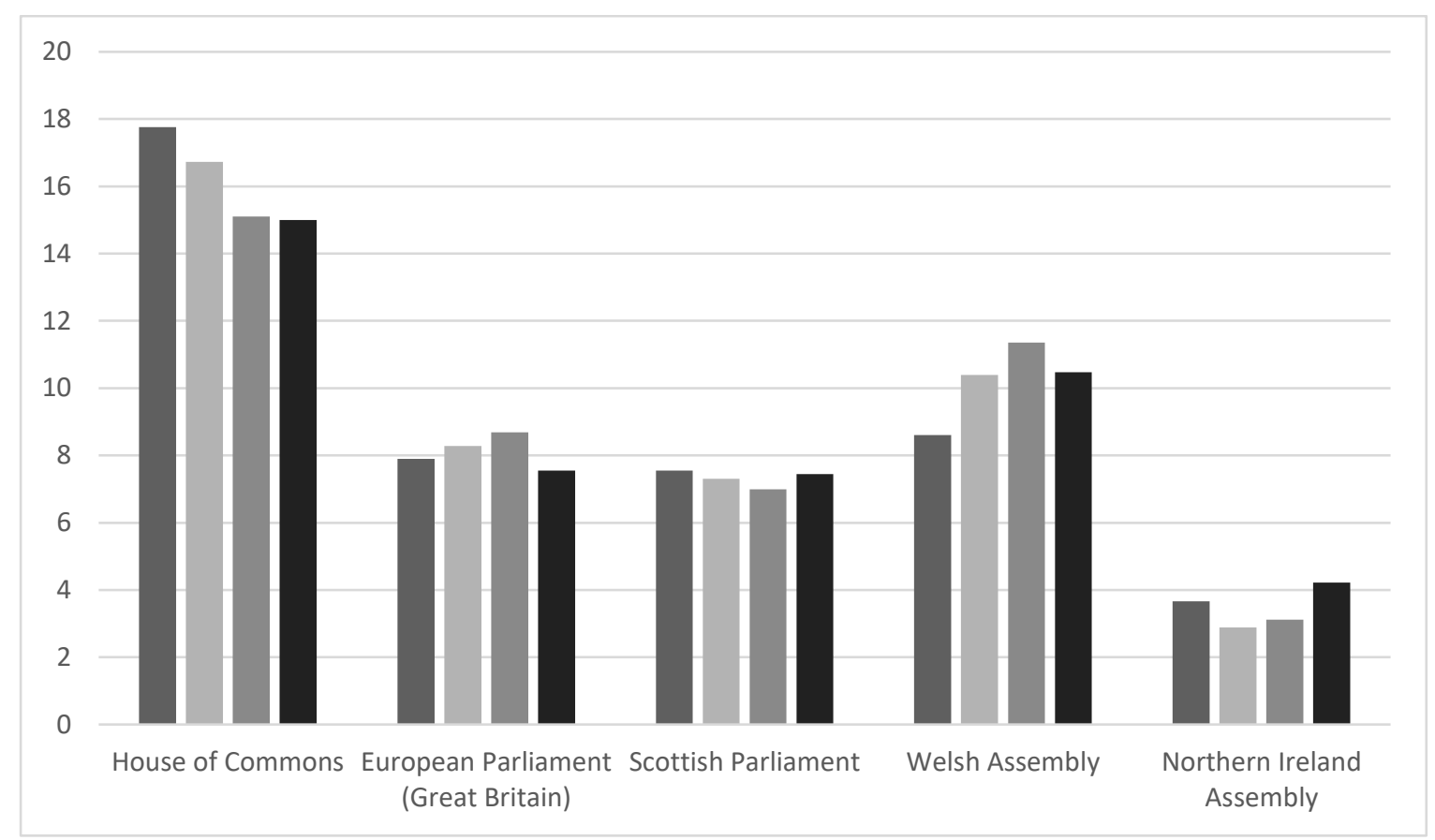

Sources: Gallagher (2015) (for general elections and devolved assembly elections); author's calculations from BBC News for European Parliament elections. 
Figure 7. The Effective Number of Parties in Recent UK Elections

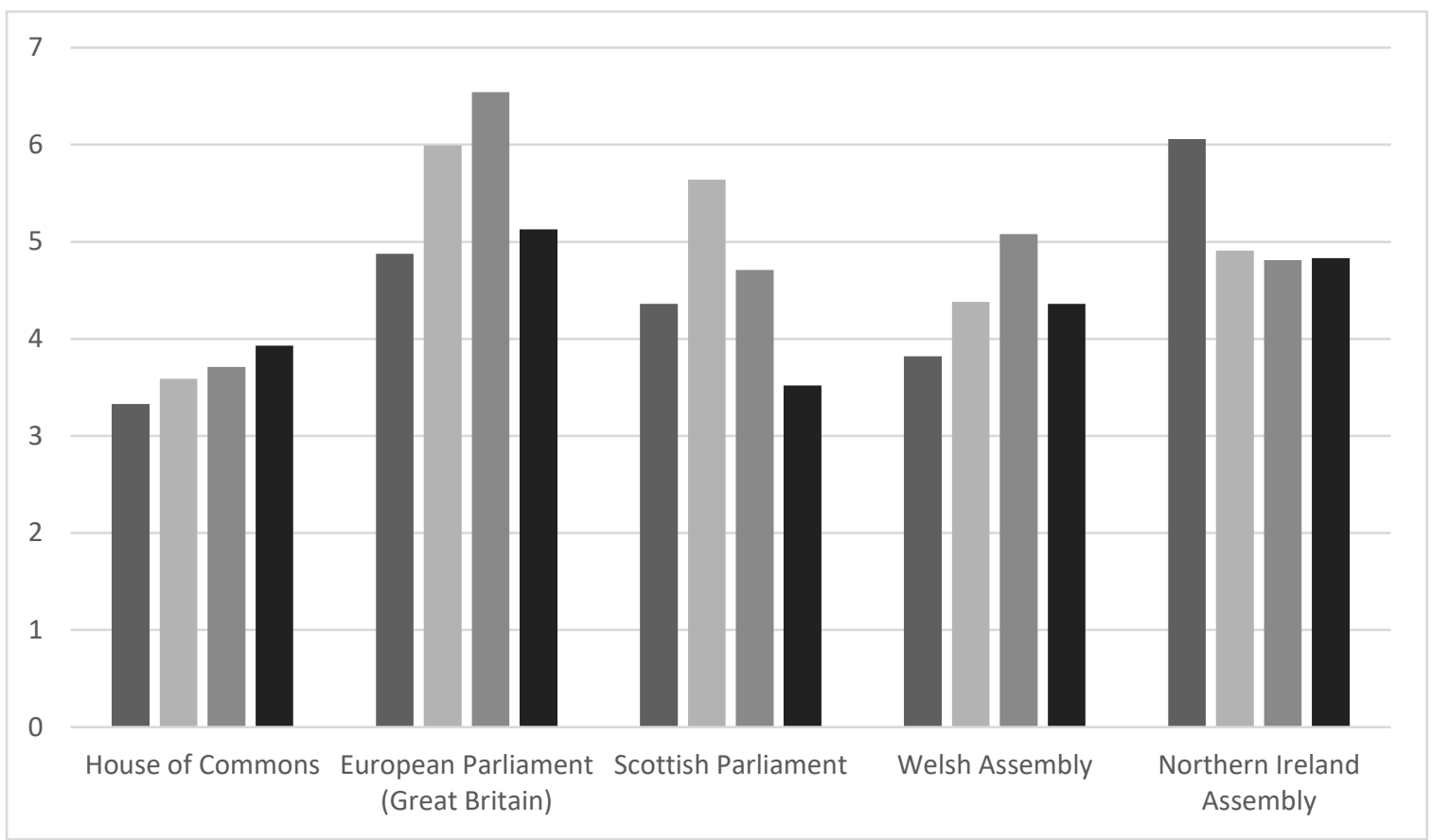

Sources: Gallagher (2015) (for general elections and devolved assembly elections); author's calculations from BBC News (2014) for European Parliament elections. 
Table 2. The 2015 Election Result under Alternative Electoral Systems (Great Britain only)

\begin{tabular}{lrrrrr}
\hline & Actual & Pure PR* & Regional PR** & STV*** & AV**** $^{* *}$ \\
\hline Conservative & 330 & 239 & 252 & 276 & 336 \\
Labour & 232 & 198 & 211 & 236 & 227 \\
UKIP & 1 & 82 & 81 & 54 & 1 \\
Lib Dem & 8 & 51 & 49 & 26 & 9 \\
SNP & 56 & 31 & 30 & 34 & 54 \\
Green & 1 & 25 & 6 & 3 & 1 \\
Plaid Cymru & 3 & 4 & 4 & 3 & 3 \\
TUSC & 0 & 1 & 0 & 0 & 0 \\
Speaker & 1 & 1 & 0 & 0 & 1 \\
\hline
\end{tabular}

* Author's calculations, using the Sainte-Laguë formula in a single district covering the whole of Great Britain.

** From Curtice (2015: 38), dividing Great Britain into the eleven European Parliament regions and applying the d'Hondt formula with a 5 per cent regional threshold.

*** From Garland and Terry (2015: 27-8, 33-5), applying STV in small multi-member districts of 2-5 seats, drawing on polling evidence on second and lower preferences.

**** From Garland and Terry (2015: 27-8, 33-5), applying AV to existing constituencies, drawing on polling evidence on second and lower preferences. 


\section{References}

BBC News (2014). Vote 2014: UK European Election Results. BBC News Online, last accessed 10 December 2015.

BBC News (2015). Election 2015: Results. BBC News Online, last accessed 10 December 2015.

Butler, David, and Donald Stokes (1974). Political Change in Britain: The Evolution of Electoral Choice, $2^{\text {nd }}$ edition. London: Macmillan.

Clarke, Harold D., David Sanders, Marianne C. Stewart, and Paul Whiteley (2004). Political Choice in Britain. Oxford: Oxford University Press.

Cowley, Philip, and Rob Ford (2014). Sex, Lies, and the Ballot Box. London: Biteback.

Cowley, Philip, and David Kavanagh (2015). The British General Election of 2015. Basingstoke: Palgrave Macmillan.

Curtice, John (2015). "A Return to Normality? How the Electoral System Operated." Parliamentary Affairs 68, supplement 1 (September), 25-40.

Dassonneville, Ruth (2015). Net Volatility in Western Europe: 1950-2014. Dataset. Leuven: KU Leuven Centre for Citizenship and Democracy. Available at http://soc.kuleuven.be/web/staticpage/11/95/eng/1197, last accessed 10 January 2015.

Denver, David (2015). "The Results: How Britain Voted." Parliamentary Affairs 68, supplement 1 (September), 5-24.

Denver, David, Christopher Carman, and Robert Johns (2012). Elections and Voters in Britain, 3rd edition. Basingstoke: Palgrave Macmillan.

Duverger, Maurice (1954). Political Parties: Their Organization and Activity in the Modern State. London: Methuen.

Eaton, George (2013). "The Tories' UKIP Problems Show Why They Should Have Supported AV." Staggers blog, 2 May. Available at www.newstatesman.com, last accessed 16 December 2015.

Farrell, David M. (2011). Electoral Systems, a Comparative Introduction. Basingstoke: Palgrave Macmillan.

Gallagher, Michael (2015). "Election Indices.” Available at www.tcd.ie; last accessed 15 January 2015. Gallagher, Michael, and Paul Mitchell, eds. (2005). The Politics of Electoral Systems. Oxford: Oxford University Press.

Garland, Jess, and Chris Terry (2015). The 2015 General Election: A Voting System in Crisis. London: Electoral Reform Society.

Geddes, Andrew, and Jonathan Tonge (2015). Britain Votes 2015. Oxford: Oxford University Press. Also published as a special issue of Parliamentary Affairs 68, supplement 1 (September).

Hanretty, Chris (2015). "Would the Conservatives Have Been Better off under AV?" LSE British Politics and Policy blog, 6 May. Available at blogs.Ise.ac.uk/politicsandpolicy/, last accessed 16 December 2015. 
Hawkins, Oliver, Richard Keen, and Nambassa Nakatudde (2015). General Election 2015. House of Commons Library Briefing Paper no. CBP7186, 28 July.

Heath, Anthony F., Stephen D. Fisher, David Sanders, and Maria Sobolewska (2011). "Ethnic Heterogeneity in the Social Bases of Voting at the 2010 British General Election." Journal of Elections, Public Opinion, and Parties 21, no. 2, 255-77.

IDEA (2015). Voter Turnout. Dataset. Available at http://www.idea.int/vt/index.cfm; last accessed 15 January 2015.

Kavanagh, Dennis, and Philip Cowley (2010). The British General Election of 2010. Basingstoke: Palgrave Macmillan.

Keen, Richard (2014). "Membership of UK Political Parties." House of Commons Library Standard Note SN/SG/5125, 16 December. Available at www.parliament.uk; last accessed 15 January 2015.

Laycock, Samantha, Alan Renwick, Daniel Stevens, and Jack Vowles (2013). “The UK's Electoral Reform Referendum of May 2011." Electoral Studies 32, no. 2 (June), 211-14.

Lent, Adam (2014). "Britain Is Facing a Crisis of Democracy but the Main Parties Cannot Respond." Democratic Audit UK Blog, 25 October. Available at www.democraticaudit.com/?p=8803; last accessed 15 January 2015.

Mackie, Thomas T., and Richard Rose (1991). The International Almanac of Electoral History, 3rd edition. Basingstoke: Macmillan.

Mitchell, James, and Arno van der Zwet (2010). "A Catenaccio Game: The 2010 Election in Scotland." Parliamentary Affairs 63, no. 4 (October), 708-25.

Nohlen, Dieter, and Philip Stöver, eds. (2010). Elections in Europe: A Data Handbook. Baden-Baden: Nomos.

Norris, Pippa (2011). Democratic Deficit: Critical Citizens Revisited. Cambridge: Cambridge University Press.

Pulzer, Peter (1967). Political Representation and Elections in Britain. London: Allen \& Unwin.

Renwick, Alan (2011). A Citizen's Guide to Electoral Reform. London: Biteback.

Sanders, David, Harold D. Clarke, Marianne C. Stewart, and Paul Whiteley (2011). "Simulating the Effects of the Alternative Vote in the 2010 UK General Election". Parliamentary Affairs 64, no. 1 (January), 5-23.

Whiteley, Paul, Harold D. Clarke, David Sanders, and Marianne C. Stewart (2013). Affluence, Austerity, and Electoral Change in Britain. Cambridge: Cambridge University Press. 